\title{
Costs row dominates patent office debate
}

Munich. Conflicting views over the future of the European Patent Office (EPO) in Munich have been brought to a head by a dispute over the appointment of a new president to succeed Paul Braendli when his second fiveyear term of office runs out next year.

Concerned at the heavy costs of financing the office, some of its 17 member states are suggesting that much of its work could be decentralized to national patent offices. Any such move, however, is being resisted by the staff of the EPO, and some former officials, who claim that in many cases excessive costs can be blamed on the policies of the member states themselves - for example, in demanding unnecessary translation of patent documents - and that decentralization would weaken theEPO's role in boosting European industry.

The EPO accepts patent applications from any country. Applicants then designate the EPO's member states in which they want patent protection, each country costing DM390 (US\$250). Total European patent fees (exclusive of patent agent charges) for seven designated countries average DM11,000.

Arguments for decentralization are closely linked to arguments for reducing the high costs of patenting through the EPO. Erich Häussler, for example, president of the German patent office which is also based in Munich, claims that some national offices could issue European patents and save the cost of running a big central organization.

"This is theoretically feasible, in particular because we can handle different languages such as English," says Häussler, who also wants a "work-sharing cooperation" with the EPO to keep fees down. This would involve the German patent office taking on some search and examination functions for the EPO.

The United Kingdom has floated the idea of five-year exchanges of patent examiners between national patent offices and the EPO, although it is not clear that this would be cheaper. Both Britain and Germany have expressed concern about the high running costs of the large riverside offices and wellpaid staff.

But Johannes van Benthem, a former president and one of the founders of the EPO, claims that any split will threaten the principles on which the office was founded, namely the harmonization of European economic policy, and improvement of Europe's ability to compete with the United States and Japan.

$\mathrm{He}$ is particularly concerned that patent searchers and examiners from different countries should continue to work closely together in order to avoid national differences and meet common standards in deciding on patent applications.

Van Benthem believes that the national policies of EPO's member states, rather than the centralized administration, have been responsible for the high cost of European patents. Contracting states insist on both the translation of every patent into their national languages, and on holding back a high proportion of the annual renewal fees that they charge for European patents.

According to the European Patent Convention (EPC), European patents can be submitted and processed in any one of the three official EPO languages, English, Ger-

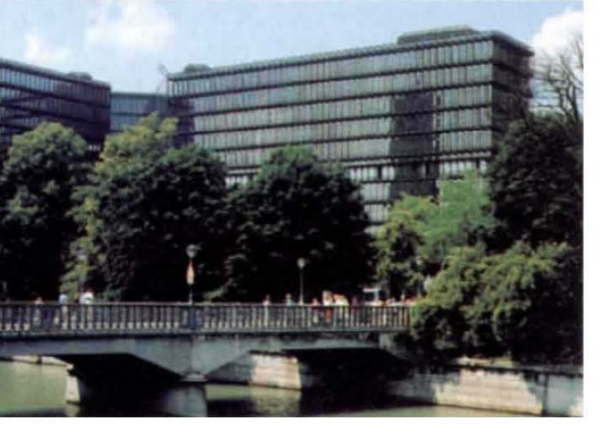

European Patent Office: too expensive?

man and French. When granted, the patent specification is published in the chosen official language; only the summarized claims of patents are translated into the other two.

A clause in the convention, however, allows all member states to ask for translations of patents registered in their country into the national language. The result, according to van Benthem, is that patentees spend about DM1 billion a year, an amount equal to the EPO's total operating costs, on translations that are rarely consulted and have no legal validity (this is the preserve of originals only). "It has moved the political and cultural problem of language into the economic arena where it does not belong," he says.

Annual renewal fees are also a source of lost income to the EPO. These are charged on all patents to keep them active; they are set independently of the EPO by the national

\section{Germany holds back on university support}

Munich. Germany's 16 Länder last week finally accepted the federal government's offer to pay DM1.8 billion over the next four years towards building and repair costs of universities - a figure that is considerably below what they had been hoping for.

The Wissenschaftsrat, Germany's influential science advisory council, had recommended that the government pay DM2.3 billion towards building costs, which would have been equalled by the Länder under the scheme of cost-sharing for universities. patent offices, and paid directly to the national offices by the patentee. The charge is intended to cover administrative costs of keeping the patent alive, but national offices return only half of the money they receive to the EPO. "This is a tax on innovation for which national patent offices do virtually nothing," says Paul Luckett, deputy chairman of the Munich branch of the staff union.

The EPO acknowledges that filing for European patents is relatively expensive, and is studying ways in which costs could in particular be reduced for small businesses. According to EPO officials, this study is looking at the two major points raised by van Benthem, accepting that these are the main sources of high costs.

But whatever the study reveals, officials of the staff union believe that the choice of the next EPO president will have a strong influence on the outcome of debate over decentralization, as some delegations, in particular the Germans, have the issue high on their agenda.

Union officials fear that an apparent rush to complete the vote before the German general elections in the middle of October could damage the EPO by reducing the opportunity for new candidates to come forward beyond those already nominated if Braendli withdraws, having failed to win sufficient support for his nomination. In particular, they are concerned that the election of the German candi= date, Ingo Kober, would bring the dispute with the German patent office in-house as a result of his political connections with the national body.

Kober is a member of the small but influential Free Democratic Party (FDP) which currently occupies key cabinet positions in Bonn, but may lose its place in the government after the general elections if it gains fewer than five per cent of the votes cast. He is currently the permanent secretary in the Ministry of Justice - whose minister, Sabine Leutheusser-Schnarrenberger, is also an FDP member - and worked for a time in the personnel department of the German patent office.

Alison Abbott

The council said this money was needed to maintain academic standards and meet new political demands on higher education, such as the expansion of Fachhochschulen (technical colleges). The federal government, however, citing general budgetary constraints, claims the figure is too high. After months of negotiation, the Länder have finally backed down. Karl-Heinz Hoffmann, head of the Wissenschaftsrat, says the compromise will have "serious consequences" for German universities. A. A. 